\title{
HEGEMON JAKO IDOL: PROPOZYCJA TEORETYCZNA
}

\author{
DARIUSZ SKÓRCZEWSKI ${ }^{1}$ \\ (Katolicki Uniwersytet Lubelski Jana Pawła II)
}

Słowa kluczowe: idol, hegemonia, kultura popularna, serial telewizyjny

Key words: idol, hegemony, popular culture, tv series

\begin{abstract}
Abstrakt: Dariusz Skórczewski, HEGEMON JAKO IDOL: PROPOZYCJA TEORETYCZNA. „PORÓWNANIA" 19, 2016. T. XIX. S. 58-69. ISSN 1733-165X. Populacja na każdym etapie egzystencji, nawet $\mathrm{w}$ najbardziej traumatogennych warunkach, potrzebuje rozrywki. Z tego względu opis doświadczenia obcej dominacji powinien uwzględnić obszar kultury popularnej jako pola artykulacji zarówno antykolonialnego sprzeciwu subalterna, jak i jego kolonialnej subordynacji. W artykule sformułowano propozycję badań nad drugim aspektem, wskazując na kulturowe mechanizmy naturalizacji hegemona w dyskursie podporządkowanych poprzez jego idolatryzację.
\end{abstract}

\begin{abstract}
Dariusz Skórczewski, HEGEMON AS IDOL: A THEORETICAL PROPOSAL. "PORÓWNANIA" 19, 2016. Vol. XIX. P. 58-69. ISSN 1733-165X. All populations need entertainment. This is true at each stage of their existence, even under most traumatic conditions. Therefore, description of experiencing foreign domination should take into account popular culture as the field of articulating both subalterns' anticolonial resistance and their colonial subordination. The paper submits a proposal of exploring the latter, pointing to cultural mechanisms of the naturalization of the hegemon in subalterns' discourse through hegemon's idolization.
\end{abstract}

\section{Zachód jako hegemon wyobrażony}

W dyskusjach nad adekwatnością postkolonialnych teoretyzacji naszej kultury wskazuje się niekiedy na brak respektu polskich peryferii i społeczną niesubordynację wobec sowieckiej metropolii, co - zdaniem krytyków postkolonializmu - miałoby przeczyć stosowalności tej metody w kontekście Polski (Borkowska). Istotnie, w odróżnieniu od stosunku Hindusów, Kanadyjczyków czy Australijczyków do

1 E-mail: dareus@kul.lublin.pl 
kultury brytyjskiej w postawach Polaków wobec Rosjan i rosyjskiej kultury, zwłaszcza w latach trwania imperium sowieckiego, rzadko można było dostrzec ślady niewymuszonej afirmacji rosyjskiej "misji cywilizacyjnej” na ziemiach polskich. Próbowano rozwiązać ten problem teoretyczny poprzez wprowadzenie kategorii hegemona zastępczego (Thompson), którym $w$ okresie sowieckiej dominacji nie przestawał być dla Polaków, raczej zmitologizowany niż realny, Zachód czy też tzw. Pierwszy Świat. Hegemon zastępczy był dla skolonizowanej populacji ideą, która pełniła terapeutyczną funkcję Nietzscheańskiej „koniecznej fikcji”: wytwarzała poczucie alternatywnej afiliacji, konkurencyjnej wobec tej narzuconej realiami geopolityki, a skupionej na obiekcie rzeczywistego pożądania.

Kategoria ta istotnie wydaje się, przynajmniej w pewnej mierze, przydatna dla objaśnienia fenomenu prozachodnich sympatii mieszkańców PRL. Troskliwie pielęgnowali oni bowiem swą "konieczną fikcję", orientując własne poszukiwania kulturowe, także w szerszym rozumieniu tego słowa, raczej ku wolnemu Okcydentowi niż ku Krajowi Rad, niosącemu wolność uciśnionym jedynie nominalnie². Jeśli cokolwiek importowano zza bliższej, a przecież jakże trudnej do przekroczenia granicy, to kierowano się pragmatyzmem a nie prestiżem, którego wschodni hegemon był w oczach wielu Polaków pozbawiony. Doświadczenie nobilitującej nawet jeśli niełatwej - styczności z metropolią było, przy całej dwuznaczności (tak sugestywnie przedstawionej np. w powieści Wysepka Andrei Levy (2006) o losach Jamajczyków przybywających do Londynu), zupełnie nieznane mieszkańcom nadwiślańskiej peryferii. Sowieckie złoto i samowary stanowiły w powszechnym odbiorze dość marną namiastkę rekompensaty za deprywację, odczuwaną przez społeczeństwo zarówno w materialnym, jak i w duchowym wymiarze kultury. Jeśli chodzi o ten drugi, to takich postaci jak Bułat Okudżawa czy Włodzimierz Wysocki nie uznawano za wytwór kultury sowieckiej, lecz raczej za zjawisko wobec niej antagonistyczne. W kulturze popularnej zaś niepodzielnie panowały produkcje zachodnioeuropejskie i amerykańskie (w ostateczności rodzime, polskie): począwszy od kina i muzyki, aż po napoje chłodzące. Nawet lubiani przez część polskiej publiczności piosenkarze jak Ałła Pugaczowa nie wzbudzali nad Wisłą takiego entuzjazmu, jak wykonawcy ze świata, którego „lepszość” zaprawiana bywała amerykańskim czy jamajskim egzotyzmem (Demis Roussos, Boney M, Goombay Dance Band i inni). Piosenki i filmy nie tylko sowieckie, lecz także z innych krajów, położonych po tej samej stronie żelaznej kurtyny, spotykały się na ogół z kontestacją, a nawet drwiną młodszego pokolenia, co wielokrotnie potem opisywali w narra-

2 Tej okcydentalnej sympatii Antoni Libera nadał funkcję ideologicznego podłoża ewokowanego przez siebie świata przedstawionego (zob. Libera). Nie jest to jednak oczywiście jedyne odnotowanie zjawiska, o którym mowa. Zarówno dyskursywne, jak i symboliczne jego ślady rozsiane są po wielu tekstach kultury okresu postpeerelowskiego: znajdują się nie tylko $\mathrm{w}$ powieściach, lecz także we wspomnieniach, filmach, a także w piosenkach. Młodsi odbiorcy mogą sięgnąć do dobrze udokumentowanych wydawnictw o szerokim zasięgu (Klaga; Kienzler). 
cjach autobiograficznych Andrzej Stasiuk, Janusz Głowacki czy Piotr Ibrahim Kalwas. Przykłady te - a znalazłoby się ich znacznie więcej - wskazują na zachodnią orientację kulturową polskiego społeczeństwa w erze komunizmu i mogą zarazem potwierdzać eksplikacyjną wartość koncepcji hegemona zastępczego.

Ilustracje te można jednocześnie uznać za dowód fiaska projektu politycznego, ekonomicznego i ideologicznego, realizowanego przez moskiewską metropolię na podbitych przez nią europejskich terytoriach. Wedle niektórych mogłoby to stanowić argument przeciwko interpretowaniu sowieckiej dominacji jako doświadczenia typu kolonialnego (Kardyni-Pelikánová 110). Wnioski takie wydają mi się jednak zbyt daleko posunięte, co - mam nadzieję - pośrednio wykażę w dalszej analizie. Nie podejmuję jej wszakże wyłącznie po to, by dowieść słuszności przeciwnej tezy. Tę wstępną część rozważań chcę zakończyć propozycją takiej modyfikacji kategorii hegemona zastępczego, która uwzględniłaby ów imaginacyjny, postulatywny a w pewnych przypadkach także megalomański - aspekt poczucia wyższości Polaków wobec wschodniego hegemona oraz ich identyfikację $\mathrm{z}$ „zachodnim rdzeniem” (Zarycki 43). Zachód w polskim dyskursie okresu PRL można, jak sądzę, postrzegać jako figurę h e g e m o n a w y o br a ż o n e g o. Idealizacja jej desygnatu - realnego Zachodu - i jego długotrwała mitologizacja odcisnęły niezatarte piętno na naszej kulturze i mentalności. Myśląc o tym, nie sposób nie zadać pytania:

\section{Co z realnym hegemonem?}

Kultura w ogóle, a w szczególności kultura społeczeństwa podporządkowanego, jest systemem zjawisk bardziej złożonym, niż by to wynikało z przyjęcia pojedynczego schematu objaśniającego, niezależnie od tego, czy schemat ten byłby oparty na koncepcji hegemona zastępczego, czy wyobrażonego. Można wykazać, w ostateczności nawet drogą indukcji, że zależność kolonialna w polskiej kulturze lat 1944-1989 generowała, prócz oporu czy odrzucenia, także postawy r e c e p t y w ne w stosunku do kultury realnego hegemona, tj. ZSRS. Główny, zachodni wektor sympatii kulturowej Polaków w okresie komunizmu nie zdołał zapobiec wytworzeniu się mechanizmu replikacji wzorów kulturowych hegemona (przyczyna tego to temat na osobne rozważania). Zjawisko to nie musiało przy tym występować na obrzeżach kultury docelowej, a przeciwnie - mogło stanowić jej główny nurt.

Wspomniana receptywność kojarzy się na ogół z jej wersją zinstytucjonalizowaną, przejawiającą się pseudospontaniczną (bo w istocie raczej wymuszoną środkami administracyjnymi) akceptacją i implementacją form obcych polskiej kulturze - socrealizmem. Jednak realizowany w oparciu o rodzime zasoby socrealizm pozostał u nas w ogólnej świadomości stylem nierodzimym, importowanym (por. Szaruga). W rezultacie - nawet gdyby uznać go za główny czynnik, kształtujący przez pewien czas pole literackie i kulturowe, ściśle $\mathrm{w}$ tym przypadku skorelowane z polem 
władzy (zob. Bourdieu) - był on czynnikiem nieżywotnym dla rozwoju literatury, odbieranym jako sztuczny wtręt. Okoliczności towarzyszące tego rodzaju quasi-kulturowemu „importowi” skłaniały do uprzedzania życzeń hegemona przez kompradorów - przedstawicieli rodzimych elit, pełniących funkcję "pasa transmisyjnego" między hegemonem a lokalną populacją, od których wyłonienia się i aktywności zależy powodzenie projektu kolonialnego (Skórczewski). Ten wymiar podległości polskiej kultury jako kultury podbitej populacji bywał już niejednokrotnie przedmiotem badań. Choć wciąż nie doczekał się, jako złożona całość, zadowalającego opracowania, nie wydoby to też jeszcze z archiwalnych tekstów wszystkich jego odsłon, to ogólny zarys zjawiska (w zależności od przyjętej metodologii i języka opisu) pozwala przewidywać zarówno kierunek wnioskowania, jak i charakter czekających nas odkryć.

Wspomniana receptywność przejawiała się również innego typu replikacją wzorców kulturowych. Mowa o sytuacji, w której oferta autoryzowanej przez hegemona instytucji (standard w sytuacji podporządkowania) spotyka się z dobrowolną, niewymuszoną akceptacją lub wręcz entuzjazmem publiczności, mimo niewątpliwej przynależności do oficjalnego obiegu kultury, a tym samym również udziału w polu. W historii PRL takie przypadki się zdarzały i wiązały się (nie rozstrzygam czy zazwyczaj, czy tylko sporadycznie) z poczuciem dyskomfortu. Czy bowiem urodzonym w niewoli przystawało darzyć atencją kulturę znienawidzonego, pogardzanego i wywołującego trwogę hegemona? Jeśli kwestia ta w ogóle budziła refleksję, to dla własnego entuzjazmu, fascynacji czy po prostu zainteresowania poszukiwano zazwyczaj uzasadnień antropologicznych („inna Rosja”, „Rosjanie, nie Sowieci”), estetycznych („piękny język rosyjski”, „wielka rosyjska literatura” - por. Sucharski') lub moralnych (na ich nienawiść odpowiemy chrześcijańską miłością).

\section{"Nasz naród scen okropnych, gwałtownych nie lubi", czyli steoretyzować rozrywkę podbitych}

Jak można wywnioskować z dotychczasowego wywodu, w artykule zwracam uwagę nie tyle na wysokoartystyczną twórczość literacką, co przede wszystkim na zjawiska kultury popularnej, w tym na wytwarzanie, recepcję, społeczne przeżywanie i reperkusje jej tekstów, których mniej lub bardziej bierna konsumpcja w postawie afirmatywnej kontemplacji o różnym stopniu zaangażowania, motywowanej pragnieniem spędzenia miło czasu, funduje swoisty rodzaj komunikacji kulturowej (por. Bates, Ferri 15). Opis doświadczenia obcej dominacji, zwłaszcza w tym

3 Praca Tadeusza Sucharskiego dotyczy problemu „stosunku do Rosji polskich pisarzy w różnym stopniu doświadczonych przez Rosję komunistyczną", którzy „[p]ublikowali [...] swe utwory na emigracji, wolni byli zatem od nacisków ideologicznych" (Sucharski 8). Niniejszy szkic podejmuje inne zagadnienie. 
jej specyficznym wydaniu, z którym mieliśmy do czynienia w Polsce w drugiej połowie $X X$ wieku, powinien uwzględnić również ten obszar ze względu na masowy odbiór wytworów popkultury i ich „długie trwanie" w przestrzeni społecznej - właściwość, która wydaje się sprzeczna z przypisywanym tekstom kultury popularnej przez jej krytyków nietrwałym, „sezonowym” charakterem. Truizmem wydaje się stwierdzenie, że populacja na każdym etapie egzystencji, funkcjonująca nawet $\mathrm{w}$ najbardziej traumatogennych uwarunkowaniach, potrzebuje rozrywki ${ }^{4}$. Skolonizowane społeczeństwo także podlega tej zasadzie, o czym przekonuje choćby wypowiedź Mickiewiczowskiego Literata IV z salonu warszawskiego.

Pomimo niebagatelnej roli, jaką odgrywa rozrywka, to zagadnienie do niedawna nie cieszyło się uwagą akademików. Patrzono na nie z uniwersyteckich katedr z wyższością zaprawioną sceptycyzmem, krytycyzmem, a nawet pogardą o podłożu estetycznym lub ideologicznym ${ }^{5}$. Włączanie tego "trywialnego" ${ }^{\prime 6}$ obszaru w pole anglojęzycznej refleksji humanistycznej, zainicjowane przez badaczy ze szkoły Cultural Studies, dokonywało się najczęściej pod parasolem i w otoczce idei marksistowskich bądź neomarksistowskich. Nie sprzyjało to silniejszemu wejściu brytyjskich studiów kulturowych do humanistyki krajów postkomunistycznych, takich jak Polska czy Rumunia, w których ze względu na niezabliźnione jeszcze doświadczenie z nieufnością i w pewnej mierze z ironią spoglądano na zachodnioeuropejską karierę nurtów odwołujących się do myśli Marksa i jego kontynuatorów. Trzeba też pamiętać, że wypracowane na tych ideach instrumenty analizy nie były neutralnymi narzędziami opisu, lecz środkam.in.erwencji w badaną rzeczywistość, mającymi doprowadzić do jej przekształcenia. Służyły nie tylko przezwyciężeniu residuów kulturowego konserwatyzmu (jak podział na kulturę „niską" i „wysoką"), lecz także zaakcentowaniu roli czynników ekonomicznych i socjalnych lub różnicy rasowej w podtrzymywaniu społecznych antagonizmów. Mniej wyczulone były natomiast na te przejawy kulturowego zróżnicowania, które dawały o sobie znać w warunkach zależności nie wewnątrzspołecznej, a przekraczającej granice pojedynczego społeczeństwa czy narodu - np. takiej, z jaką mieliśmy do czynienia w krajach Europy Środkowo-Wschodniej w stosunku do ZSRS, którego podboje legitymizowane były m.in. właśnie hasłami marksistowskimi. W konsekwencji teoretyzacje kultury

4 Rozpoznaniu natury tej potrzeby poświęcono wiele prac z zakresu filozofii kultury, psychologii społecznej i psychologii mediów (zob. Postman; Singhal, Rogers; Rubin, Perse). Analizy te wskazują np. na takie motywacje jak poszukiwanie ekscytacji, chęć zabicia czasu, voyeryzm, odprężenie poprzez ucieczkę od rzeczywistości itp. Nie uwzględnia się w nich natomiast na ogół udziału czynników swoistych dla populacji krajów tzw. Drugiego Świata, niestandardowych dla wysoko rozwiniętych, demokratycznych społeczeństw, jak resentyment, poczucie deprywacji i stłamszenia, cywilizacyjna i polityczna alienacja w stosunku do Pierwszego Świata etc.

5 Więcej o przyczynach tego stanu rzeczy zob. Bates, Ferri. Na gruncie polskim pierwszymi próbami jego przezwyciężenia były prace Krzysztofa Teodora Toeplitza (Toeplitz 1972; 1978) i Antoniny Kłoskowskiej (Kłoskowska).

$6 \mathrm{~W}$ przeszłości niejednokrotnie podnoszono kwestię „trywialności” rozrywki, czyniąc z tego argument przeciwko przyznaniu jej statusu przedmiotu badań naukowych (Shusterman 291). 
oparte na myśli Karla Marksa, Antoniego Gramsciego, przedstawicieli szkoły frankfurckiej, a także na pracach Maxa Webera i Pierre'a Bourdieu, koncentrując się na zagadnieniach dominacji czy też hegemonii klasowej $\mathrm{i}$ kulturowych śladach reprodukcji nierówności społecznych na tym tle, nie podjęły przynajmniej części zagadnień charakterystycznych dla naszego regionu. Mowa o zjawiskach wynikających z innego niż preferowane $w$ tamtych modelach podłoża - nie klasowego czy rasowego, lecz podłoża ",białego kolonializmu”, opartego na podboju, dominacji i wyzysku terytoriów przyległych, zamieszkiwanych przez ukształtowane, świadome siebie organizmy narodowe o długiej historii i własnych, odrębnych tradycjach kulturowych.

Niniejszy artykuł wskazuje możliwość uzupełnienia tego braku poprzez zaproponowanie takiej teoretyzacji kultury, a dokładniej jej popularnego segmentu, która nie tylko uwzględniłaby swoistość doświadczenia społeczeństwa podporządkowanego w warunkach kolonializmu typu sowieckiego, lecz także uznała to doświadczenie za paradygmatyczne dla kultury populacji subalternów. Szczególnie ważna z punktu widzenia studiów postkolonialnych nad naszym regionem wydaje się odpowiedź na pytanie, w jaki sposób w kulturze popularnej dokonywała się naturalizacja władzy hegemona - władzy postrzeganej jako nie swoja, inherentnie obca, wroga, a mimo to, paradoksalnie, władzy przeszczepionej i przyjętej na rodzimy grunt za pomocą pewnych praktyk kulturowych, gdzie została zaakceptowana i wchłonięta w krwiobieg tej kultury jako jej rodzimy element. Otóż prawomocna wydaje się teza, iż integralnym składnikiem i warunkiem tego procesu był idol - antyteza przemocy - i drugi, paralelny w stosunku do niej, kanał transmisji kolonialnej władzy. By dowieść słuszności tego stwierdzenia, należałoby przeprowadzić studium przypadku, na co jednak nie pozwala skromna objętość niniejszego szkicu. Dlatego kończę go ogólnym wprowadzeniem w problematykę idola (w) komunistycznej peryferii oraz wskazaniem - w trybie egzemplifikacji - zjawiska, którego szczegółowa analiza wymaga obszerniejszego studium ${ }^{7}$.

\section{Idol (w) komunistycznej peryferii}

Idol - zjawisko stosunkowo młode w kulturze, jeśli wyabstrahować je z pierwotnego, religijnego kontekstu (Fumaroli) - kojarzy się powszechnie z takimi wyróżnikami jak ponadprzeciętna popularność (Pawełczyk 257) i związana z tym powszechna rozpoznawalność, status ikoniczny, a także wypełnianie deficytów, faktycznych bądź wyobrażonych pod wpływem pojawienia się jednostki o pewnej unikatowej właściwości, która z racji posiadania określonej cechy zyskuje pozycję autorytetu, wzoru, obiektu podziwu, a nawet zazdrości (Jakubowski). Nałożenie

7 Rzecz ukaże się w tomie Idol w kulturze pod redakcją A. Fitasa, E. Fiały i D. Skórczewskiego. 
się na siebie tych parametrów prowadzi do wytworzenia się wokół idola wspólnoty interpretacyjnej oraz do jego autonomizacji. Ta ostatnia polega na oderwaniu się idola od pierwotnego, macierzystego kontekstu (sytuacji bądź tekstu kultury, będących miejscem publicznego zaistnienia) i rozpoczęciu egzystencji odeń niezależnej, lecz zarazem retroaktywnie ów kontekst przywołującej.

Mówiąc o idolu w specyficznym kontekście politycznym, jakim był PRL, trzeba zastrzec, iż nie mamy tu do czynienia z figurą idola w znaczeniu, w jakim używa się tego słowa w marketingu politycznym $\mathrm{w}$ demokratycznych społeczeństwach (Hordecki). W interesującym nas przypadku idol odgrywał zupełnie inną rolę. Odmienne były warunki, w jakich egzystował, a raczej w jakich jego egzystencja była wprawiona w ruch i podtrzymywana instrumentami polityki kulturalnej. Nie przestając być figurą a trakcji - atrakcyjność wizerunku to warunek sine qua non idola, jego pierwszorzędna i konstytutywna cecha - nie pełnił funkcji stricte pragmatycznej we wspomnianym znaczeniu, tzn. nie został wprowadzony do polityki dla pozyskania elektoratu za pośrednictwem zaangażowanych do tego celu dyskursów kulturalnych wolnego (suwerennie o sobie stanowiącego) społeczeństwa. W komunistycznej peryferii, w społeczeństwie podporządkowanym był bezalternatywną figurą dyskursu hegemonicznego, służącą legitymizacji porządku władzy właśnie na zasadzie hegemonii w Gramsciańskim ujęciu, tzn. poprzez stworzenie iluzji, iż porządek władzy jest dobry i korzystny dla podporządkowanych, zgodny z ich pragnieniami, upodobaniami i celami życiowymi.

Mimo zmiennego kontekstu (geo)politycznego oraz różnego stopnia uczestnictwa w sprawowaniu władzy idol w proponowanym tu rozumieniu charakteryzuje się wieloma cechami społeczno-osobowościowymi, uzdatniającymi go nie tylko do roli bohatera, wzoru i obiektu emocjonalnego kultu. Prócz atrakcyjności mogą go również cechować: charyzma, skuteczność, zdecydowanie oraz konsekwencja - a więc te przymioty, którymi winna się wykazać tzw. mocna osobowość, aspirująca do roli przywódcy. Wykreowana środkami kulturowymi i wylansowana medialnie postać o takich „parametrach” ma predyspozycje do tego, by zdyskontować je w przestrzeni ponadindywidualnej. Posiadanie powyższych zalet sugeruje przecież zdolność do udźwignięcia odpowiedzialności za grupę, w imieniu której idol występuje w komunistycznej peryferii i której sympatię pragnie pozyskać ${ }^{8}$. Dzięki temu figura ta może pełnić $\mathrm{w}$ dyskursie władzy istotną funkcję z punktu widzenia kapitału symbolicznego peryferii. U której zikon PRL-owskiej popkultury odnajdujemy wymienione cechy?

8 Cechy te wymienia się współcześnie w kontekście kreowania wizerunku polityków (Jeziński 2005: 115). Idol w tym rozumieniu, nie przestając być obiektem powszechnego uznania, podzi$\mathrm{wu}$, a nawet kultu, jest zarazem pewnym typem wizerunku politycznego, obok innych możliwych jego odmian, takich jak profesjonalista, mąż stanu, amant, heros, zwykły człowiek, szarak, błazen, ekscentryk oraz luzak. Typologię tę, wprowadzoną przez Serge'a Albouyego (Albouy), rozszerzono na naszym gruncie m.in. o figurę idola (zob. Jeziński 2004). Nie wszystkie typy mogły oczywiście zaistnieć w społeczeństwie komunistycznym, to jednak temat na inne studium. 


\section{Hegemon $w$ narodowym panteonie}

Stanisław Mikulski dostąpił pośmiertnie zaszczytu, jaki spotyka tylko najważniejsze postaci naszego życia publicznego: 5 grudnia 2014 r. Parlament RP uczcił go minutą ciszy, umieszczając go tym samym w polskim panteonie. Co zaważyło na takiej decyzji prezydium Sejmu? Pytanie to prowadzi do ogólniejszej refleksji, którą tu jedynie sygnalizuję: co stanowi o tym, że jednostka może zostać bohaterem zbiorowości? Jaki mechanizm stoi za społecznym kreowaniem herosów?

Jeśli uznać słuszność tezy, iż „naród w swych bohaterach sam siebie czci i pokrzepia" (Kijowski 13), to w jej świetle obsadzenie Mikulskiego-Klossa w roli narodowego herosa czy też gieroja nabiera szczególnego znaczenia. Co takiego Polacy mogli widzieć w Klossie, co tłumaczyłoby ikoniczność tej postaci, rzutującą na całe dalsze publiczne życie aktora i przesłaniającą jego wszystkie późniejsze role? Dlaczego Kloss-Mikulski stał się idolem kilku pokoleń Polaków i pozostaje nim aż dotąd, otrzymawszy post mortem potwierdzenie ze strony najwyższego urzędu w państwie, wyrażone gestem Parlamentu VII kadencji - pośmiertnym uczczeniem odtwórcy roli minutą ciszy?

Bohater Stawki większej niż życie podsuwał telewidzom ideologię (rozumianą jako matryca interpretacji rzeczywistości), która była swego rodzaju „konieczną fikcją" podbitych. Fikcja ta oferowała kolektywne marzenie o przechytrzeniu opresora i kompensację poniesionych strat oraz nierealnych dążeń, zmaterializowaną w formie zwycięstwa wieńczącego fabułę. Czyż podwójna gra Klossa nie była spełnieniem utajonych pragnień społeczeństwa, pragnień dwojakiego rodzaju: kompensacyjnych oraz tych podszytych kolonialną mimikrą? Pragnień, by po serii wojennych i powojennych traum choć przez chwilę transpasywnie nacieszyć się byciem "po drugiej stronie barykady" - przynależnością do enklawy zwycięzców ${ }^{9}$ - a także pragnień, by w przebraniu przechytrzyć przełożonych, jednocześnie $\mathrm{z}$ dala od ich wzroku postępując inaczej, żeby wyjść „na swoje”? Czy taki bohater nie dawał widzom alibi w ich położeniu, z jednej strony dostarczając rodakom-„,niewolnikom” jouissance w postaci bohatera odgrywającego „pana”, a z drugiej - udzielając nie wprost przyzwolenia na szachrajstwa i machlojki, po które sięgają ludzie żyjący pod opresją, by wymknąć się dyskursowi kolonialnej władzy poprzez ucieczkę w „przebiegłą układność" (Bhabha 89)? Pytania te stawiają w nowym świetle zagadnienie kulturowej idolatrii i jej etycznych implikacji w warunkach sowieckiej dominacji. Rodzą również kolejne refleksje, które jednak nie są przedmiotem tego studium:

9 O dwuznaczności tego aspektu kreacji Klossa pisano, zwracając uwagę na - nieobecny z oczywistych względów w powojennej polskiej kulturze - motyw delektowania się pozycją zwycięzcy: „Rozkosze tego życia towarzyszą naszemu bohaterowi nie tylko w zakresie komunikacji i swobody poruszania się. Wycie syren ulicznej łapanki stanowi sygnał do popłochu dla wszystkich przechodniów, ale nie oznacza niczego dla Klossa, który może spokojnie przejść przez kordon obławy, ignorując grozę sytuacji" (Toeplitz 1972: 164). 
jak w tym kontekście interpretować późniejsze, pamiętne kreacje estradowe i filmowe Mikulskiego - konferansjera na Festiwalu Piosenki Żołnierskiej w Kołobrzegu, Pana Samochodzika w ekranizacji powieści Zbigniewa Nienackiego i Wujka Dobra Rada w komedii Stanisława Barei Miś?

Nawet dziś nie sposób przejść do porządku dziennego nad faktem, iż „Kloss polski bohater narodowy, chodzi w mundurze niemieckim, a jest na usługach wywiadu radzieckiego" (Mętrak 18). Można powiedzieć, że Mikulski jest w serialu emblematyczną figurą „polskiego losu”, ukazaną jednak, a raczej odgrywaną, z pozycji kulturowego i politycznego podporządkowania, nie zaś z perspektywy neutralnej, zakładającej możliwość samoartykulacji podmiotu. Uczestnicząc w pozorowaniu sprawczości odtwarzanego przez siebie bohatera o nazwisku Kolicki, Mikulski demonstruje $\mathrm{w}$ istocie - na poziomie sensów implikowanych - że jest skolonizowanym „Innym”, którego wartość stanowi funkcję skuteczności realizacji aktorskich zadań, zdefiniowanych $\mathrm{w}$ zarysie przez realnego hegemona Polski lat sześćdziesiątych XX wieku, tj. Związek Sowiecki, a doprecyzowanych i powierzonych przez lokalnych decydentów polskich peryferii. Jego zachowaniem rządzi zasada kolonialnej mimikry, znakomicie zresztą stematyzowana w serialowej fabule.

Kolicki (Kloss) chętnie korzysta z przywilejów oficera zwycięskiej armii, a przy tym zgrabnie żongluje swą tożsamością, resumé i emploi, dostosowując taktykę do oczekiwań aktualnego otoczenia, strategię zaś na pozór rezerwując dla siebie jako Polaka, a faktycznie podporządkowując ją celom wytyczonym przez opresora. Wszystko to natomiast - zdarzenia i działania postaci - przedstawione jest tak, by skolonizowana publiczność czerpała z obrazu podwójną przyjemność: ulegała iluzji, iż "górą są nasi", przyjmując proponowany w serialu fantazmat siły i niezawisłości - dwóch walorów pozostających poza zasięgiem podbitych ${ }^{10}$ - oraz odnajdywała uzasadnienie dla postaw $\mathrm{w}$ swoim mniemaniu wallenrodycznych. Spoza fikcji Stawki większej niż życie przezierała bowiem co rusz, ukryta za mundurem protagonisty, figura rzeczywistego hegemona, sterującego całością filmowego przedsięwzięcia i kontekstu społecznego oraz geopolitycznego, w jakim było ono realizowane. Konsolacja osiągnięta tą drogą była zatem pozorna. W realizowanej z zimną krwią „wallenrodycznej” ${ }^{11}$ rozgrywce agenta J-23, skrojonej na miarę socjalistycznej popkultury ery zimnej wojny, odbijała się niczym w lustrze machiaweliczna postawa samego aktora, który pod maską szpiega wyprowadzającego w pole Niemców

10 Zwracano uwagę na „wyniosłą przewagę”, jaką posiada Kloss „nad wszystkimi innymi przedstawicielami wywiadu czy konspiracji, z którymi współpracuje. Kloss jest od nich po prostu nieporównanie lepszy. [...] Bez Klossa, któremu podporządkowują się bez zastrzeżeń, są bezradni i zagubieni, on zaś rozwiązuje z łatwością ich wszystkie kłopoty [...]. Otrzymujemy tu bodaj po raz pierwszy w naszej tradycji egzemplarz bohatera, w którego losie i postawie zarówno porażka jak i wszelka tragiczność są zgoła nieobecne" (Toeplitz 1972: 168-170).

11 Ironicznie komentowano postawę bohatera serialu: „Nie ulega [...] kwestii, że Kloss jest bądź najlepiej zakonspirowanym, bądź też najbardziej beztroskim Wallenrodem, jakiego poznaliśmy dotychczas" (Toeplitz 1972: 172). 
dawał widzom możliwość delektowania się namiastką uniwersalnego oporu wobec rządzących w imię Sprawy (cokolwiek zostałoby podstawione pod to słowo), bez ponoszenia $z$ tego tytułu jakichkolwiek kosztów.

Wszystko to jednak było tylko p o z o r e m rozszczelnienia ściśle kontrolowanego przekazu, który tak naprawdę w ten sposób jedynie utrwalał przewagę hegemona. Ucieleśnieniem figury hegemona stał się nie kto inny, tylko główny bohater serii Hans Kloss. To ze względu na dwuznaczność tej kreacji aktor stał się postacią kanoniczną nie tylko w dziejach polskiej telewizji, a tym samym kultury masowej, lecz także w zbiorowej wyobraźni Polaków, którą wówczas zawładnął niemal bezwyjątkowo: od najmłodszego do najstarszego pokolenia, łącznie z politykami i parlamentarzystami, o czym mogliśmy się niedawno przekonać, i którą wciąż organizuje.

O Klossie-Mikulskim można zatem mówić jako o hegemonie z trzech powodów:

Jako Hans Kloss jest on synekdochą Niemiec - hegemona okresu II wojny, konserwowanego w tym statusie w retrospektywnych narracjach pokroju Stawki większej niż życie przez zimnowojenny układ. Hegemon ten zostaje przezwyciężony przez nowego hegemona, Związek Sowiecki, którego władza rozciąga się od czasu diegezy po czas realizacji i założonego odbioru serialu.

Jako Stanisław Kolicki zostaje agentem sowieckiego wywiadu: będąc wprawdzie de iure żołnierzem polskim, de facto jest posłusznym funkcjonariuszem sowieckiego imperium - rzeczywistego hegemona zarówno w okresie wojny, jak i podczas realizacji serialu.

Jako aktor Stanisław Mikulski występuje w roli kustosza mitu, legitymizującego podporządkowanie Polski sowieckiej dominacji, przez co uczestniczy w realizacji wytycznych polityki kulturalnej na terenie peryferii moskiewskiej metropolii, działając na korzyść aktualnego hegemona.

Z powyższej, nader okrojonej analizy nasuwa się wniosek, że idolatryczna otoczka wokół odtwórcy roli Hansa Klossa nie kryje w sobie wyłącznie niewinnego gwiazdorskiego celebrytyzmu, jak skłonni bylibyśmy myśleć w dobie kultu serialu. Tkwią w niej bowiem skondensowane miazmaty zależności o podłożu kolonialnym, których wciąż niewyparta obecność stawia pod znakiem zapytania skuteczność procesu przepracowywania przez społeczeństwo (post)kolonialnej traumy.

\section{BIBLIOGRAFIA}

Albouy, Serge. Marketing et communication politique. Paris: L'Harmattan, 1994.

Borkowska, Grażyna. „Perspektywa postkolonialna na gruncie polskim - pytania sceptyka”. Teksty Drugie 5 (2010). S. 40-52.

Bates Stephen, Ferri Anthony J. „What's Entertainment? Notes Toward a Definition”. Studies in Popular Culture 33: 1 (2010). S. 1-20. 
Bhabha, Homi. Miejsca kultury. Przeł. Tomasz Dobrogoszcz. Kraków: Wydawnictwo Uniwersytetu Jagiellońskiego, 2010.

Bourdieu, Pierre. Reguty sztuki. Geneza i struktura pola literackiego. Przeł. Andrzej Zawadzki. Red. M. Sugiera. Kraków: Universitas, 2001.

Fumaroli, Marc. The Christian Critique of Idolatry. Przeł. Benjamin Storey. Idol Anxiety. Red. J. Ellenbogen, A. Tugendhaft. Stanford: Stanford University Press, 2011. S. 32-40.

Hordecki, Bartosz. „Kreowanie wizerunków a demokracja - w poszukiwaniu hipotezy badawczej”. Marketing polityczny. Szansa czy zagrożenie dla wspótczesnej demokracji? Red. P. Pawełczyk. Poznań: Instytut Nauk Politycznych i Dziennikarstwa UAM, 2007. S. 141-146.

Jakubowski, Jakub. „Idol - wizerunek polityczny w czasach popkultury”. Web. 13.03.2016.

<http://www.academia.edu/12153906/Idol_wizerunek_polityczny_w_czasach_popkultury>

Jeziński, Marek. Marketing polityczny a procesy akulturacyjne. Przypadek III Rzeczpospolitej. Toruń: Wydawnictwo Uniwersytetu Mikołaja Kopernika, 2004.

Jeziński, Marek. „Wizerunek polityczny jako element strategii wyborczej”. Kampania wyborcza: marketingowe aspekty komunikowania politycznego. Red. B. Dobek-Ostrowska. Wrocław: Wydawnictwo Uniwersytetu Wrocławskiego, 2005. S. 115-132.

Kardyni-Pelikánová, Krystyna. „Na marginesie postkolonialnych odczytań w relacjach polskiej i czeskiej literatury". Porównania 6 (2009). S. 121-135.

Kienzler, Iwona. Życie w PRL i strasznie, i śmiesznie. Warszawa: Bellona, 2015.

Kijowski, Andrzej. „Jeszcze o Kościuszce i o narodowych mitach”. Życie Literackie 26 (1979). S. 13.

Klaga, Wacław. Blaski i nędze życia w PRL. Kraków: Biały Kruk, 2014.

Kłoskowska, Antonina. Kultura masowa: krytyka i obrona. Warszawa: PWN, 1980.

Levy, Andrea. Wysepka. Przeł. Izabela Matuszewska. Warszawa: Albatros, 2006.

Libera, Antoni. Madame. Kraków: Znak, 1998.

Mętrak, Krzysztof. Dziennik. T. 1: 1969-1979. Wyb., oprac. i wstęp Wacław Holewiński. Warszawa: Iskry, 1997.

Pawełczyk, Piotr. „Osobowość jako źródło władzy w warunkach demokracji masowej”. Prawne, ekonomiczne i polityczne aspekty funkcjonowania mediów i kreowania ich zawartości. Red. P. Dudek, M. Kuś. Toruń: Wydawnictwo Adam Marszałek, 2009. S. 260-265.

Postman, Neal. Amusing Ourselves to Death. New York: Penguin, 1986.

Rubin Alan M., Perse Elizabeth M. „Audience activity and soap opera involvement”. Human Communication Research. 14: 2 (1987). S. 246-268.

Shusterman, Richard. „Entertainment: A Question for Aesthetics”. British Journal of Aesthetics 43: 3 (2003). S. 289-307.

Singhal Arvind, Rogers Everett M. „A Theoretical Agenda for Entertainment-Education”. Communication Theory 12: 2 (2002). S. 117-135.

Skórczewski, Dariusz. Teoria - literatura - dyskurs. Pejzaż postkolonialny. Lublin: Wydawnictwo KUL, 2013.

Sucharski, Tadeusz. Polskie poszukiwania „innej Rosji”. O „nurcie rosyjskim” w literature Drugiej Emigracji. Gdańsk: Słowo/Obraz Terytoria, 2008.

Szaruga, Leszek. Powinności literatury i inne szkice krytyczne. Kraków: Universitas, 2008.

Thompson, Ewa M. „W kolejce po aprobatę”. Europa - Tygodnik Idei 180 (2007). S. 8. 
Toeplitz, Krzysztof Teodor. Mieszkańcy masowej wyobraźni. Warszawa: PIW, 1972.

Toeplitz, Krzysztof Teodor. Wszystko dla wszystkich. Kultura masowa i człowiek wspótczesny. Warszawa: Wiedza Powszechna, 1978.

Zarycki, Tomasz. Ideologies of Eastness in Central and Eastern Europe. London-New York: Routledge, 2014. 